\title{
HUBUNGAN DAYA LEDAK OTOT TUNGKAI DENGAN KEMAMPUAN SMASH PADA EKTRAKURIKULER BOLAVOLI DI SMP NEGERI 6 KOTA LUBUKLINGGAU
}

\author{
Handro Gustiawan ${ }^{1}$, M. Rusni Eka Putra ${ }^{2}$, Muhammad Suhdy ${ }^{3}$ \\ ${ }^{123}$ Pendidikan Jasmani Kesehatan dan Rekreasi, STKIP PGRI Lubuklinggau, Indonesia
}

\begin{tabular}{|c|c|}
\hline ARTICLE INFORMATION & 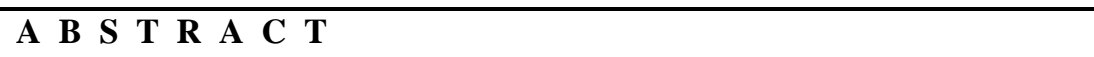 \\
\hline $\begin{array}{l}\text { Received: Juli 26, } 2021 \\
\text { Revised: Agustus 12, } 2021 \\
\text { Available online: Desember } 30,2021\end{array}$ & \multirow{5}{*}{$\begin{array}{l}\text { The problem in this study is that volleyball extracurricular students at SMP Negeri } 6 \\
\text { Lubuklinggau City still have jumps and punches in the weak category, this is due to } \\
\text { the weak power of the students' leg muscles which causes the smash to be performed } \\
\text { less than optimal. The research objective was to determine whether there was a } \\
\text { relationship between the explosive power of the leg muscles and the smash ability of } \\
\text { volleyball players at SMP Negeri } 6 \text { Lubuklinggau City. The variables of this study } \\
\text { were the leg muscle explosive power as the independent variable, and the smash } \\
\text { ability was the dependent variable. This type of research is correlational research. } \\
\text { This research was conducted on } 14 \text { male volleyball extracurricular students at SMP } \\
\text { Negeri } 6 \text { Lubuklinggau City. The instrument for collecting the explosive power of the } \\
\text { leg muscles used the vertical jump test and the smash used the smash ability test. The } \\
\text { data analysis technique used the product moment correlation formula. The results of } \\
\text { the study showed that there was a relationship between the leg muscle explosive } \\
\text { power (x) and the volleyball smash ability (y), the calculation result was rxy = 0.55 } \\
\text { from this value can be categorized as moderate. The results stated that there was a } \\
\text { significant relationship between the explosive power of leg muscles on the smash } \\
\text { ability of volleyball extracurricular students at SMP Negeri } 6 \text { Lubuklinggau City, this } \\
\text { was stated based on hypothesis testing where thit }=2.280>t \text { tab }=2.178 \text {. }\end{array}$} \\
\hline KEYWORDS & \\
\hline $\begin{array}{l}\text { Keywords: leg muscle explosive power, } \\
\text { volleyball smash }\end{array}$ & \\
\hline CORRESPONDENCE & \\
\hline E-mail: handrogustiawan@gmail.com & \\
\hline
\end{tabular}

\section{PENDAHULUAN}

Olahraga dalam kehidupan manusia mempunyai peranan yang penting, dalam kehidupan modern sekarang ini manusia selalu melakukan aktivitas olahraga tidak bisa dipisahkan dari kegiatan olahraga, baik untuk meningkatkan prestasi maupun kebutuhan untuk menjaga kondisi tubuh agar selalu tetap sehat. Kegiatan olahraga di Indonesia disamping menjadi tanggung jawab pribadi dan masyarakat masih diperlukan adanya dukungan dari pemerintah agar tujuan olahraga dapat lebih baik dan berhasil. Kekuatan kebijakan olahraga dapat dituangkan ke dalam deklarasi Yogyakarta 2004 (Kemenpora) dan UU No. 3 Tahun 2005 (Sistem Keolahragaan Nasional/SKN) yang menyatakan bahwa olahraga adalah segala kegiatan yang sistematik untuk mendorong, membina, serta mengembangkan potensi jasmani, rohani, dan sosial. Tujuan olahraga bukan hanya untuk pembangunan fisik tubuh saja melainkan juga membangun mental, spiritual dan prestasi, sehingga antara jasmani dan rohani akan berkembang dengan seimbang, serasi dan selaras dengan hakekat dalam pembangunan nasional. 


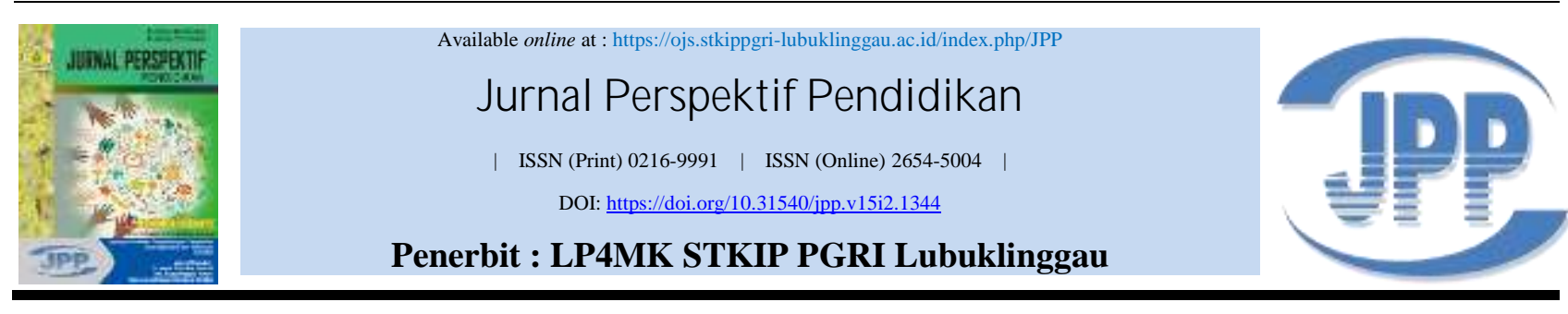

Olahraga merupakan komponen yang sangat penting dan strategis dari segala aspek kehidupan manusia. Dalam dunia olahraga dikenal berbagai macam cabang olahraga, salah satunya adalah cabang bolavoli. Bolavoli menjadi cabang olahraga permainan yang menyenangkan karena dapat beradaptasi dengan berbagai kondisi. Bolavoli dapat dimainkan dengan jumlah pemain yang bervariasi, seperti voli pantai dengan jumlah pemain 2 orang atau dengan jumlah pemain 6 orang yang biasa digunakan. Selain itu olahraga bola voli dapat dimainkan oleh berbagai usia dari anakanak sampai dewasa. Akan tetapi tidak semua yang dapat bermain bolavoli dikatakan pandai bermain bolavoli. Menurut (Achmad, 2016:79) olahraga bolavoli dapat lakukan di atas lapangan yang berbentuk persegi panjang, dengan panjang 18 meter dan lebar 9 meter, ditengah-tengah dipasang jaring atau net sebagai pembatas dengan tinggi 2,24 meter untuk putri dan 2,43 untuk putra, dengan lebar satu meter, yang terbentang kuatdan dapat dilakukan didalam ataupun di luar ruangan. Perkembangan permainan bola volidi zaman modern ini semakin dapat diterima dan dapat digemari oleh berbagai golongan, gejala ini dapat terjadi karena permainan bolavoli merupakan permainan yang cukup menarik untuk dilakukan karena banyak memiliki pola variasi penyerangan dan variasi bertahan.

Seorang atlet untuk dapat menguasai permainan bolavoli dengan baik dan sempurna, maka diperlukan penguasaan teknik dasar secara baik pula. Dari sekian banyak teknik dasar yang ada dalam permainan bolavoli salah satunya smash, Menurut (Anam, 2015:42) smash adalah pukulan yang utama dalam penyerangan dalam usaha mencapai kemenangan. Smash merupakan teknik yang selalu digunakan untuk menyerang dan menghasilkan angka serta meraih kemenangan. Hal ini dikarenakan smash merupakan suatu pukulan yang keras dan dilakukan dengan memanfaatkan keberadaan bola di udara atau diatas net yang diarahkan pada suatu sasaran tertentu di petak lawan yang berguna untuk mematikan pertahanan lawan serta mendapatkan angka dalam permainan bolavoli.

Pelaksanaan teknik smash diperlukan beberapa faktor-faktor penentu seperti langkah awalan, tolakan untuk meloncat, memukul bola saat melayang diudara, saat mendarat kembali setelah memukul bola. Dalam melakukan gerakan smash juga membutuhkan komponen kondisi fisik untuk mendukung hasil smash yang baik dan sempurna. Menurut (Setiono, 2013:43) komponen kondisi fisik adalah kelincahan (agility), keseimbangan (balance), kekuatan (strength), koordinasi 


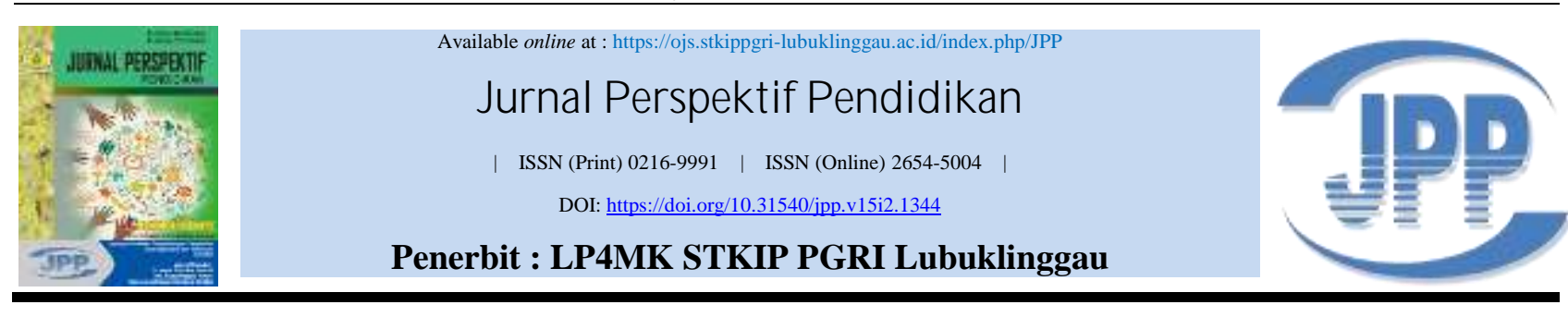

(coordination), daya tahan otot kardiovaskuler (endurance), kelentukan (flexibilty), kecepatan gerak reaksi (speed), daya ledak otot (power).

Daya ledak otot tungkai merupakan salah satu faktor sangat penting dan harus diperhatikan dalam permainan bolavoli terutama pada saat melakukan pukulan sehingga dengan memiliki daya ledak otot tungkai yang baik, akan menghasilkan smash yang lebih baik pula. Tinggi rendahnya daya ledak otot tungkai juga mempengaruhi hasil dari kemampuan smash, semakin tinggi daya ledak otot tungkai maka semakin tinggi pula untuk meraih bola, semakin tinggi lompatan pada saat melakukan smash maka bola yang dihasilkan akan semakin baik dan apabila bola yang di hasilkan baik maka jarak jatuhnya bola akan semakin dekat dan waktu yang ditempuh akan semakin singkat. Kekuatan adalah kekuatan otot melibatkan sekelompok otot yang sedang berkontraksi terhadap daya ledak, kecepatan dan kelentukan melakukan gerakan dalam ruang gerak sendi secara maksimal.

Ekstrakurikuler bola voli di SMP Negeri 6 Kota Lubuklinggau yang diikuti oleh siswa putra dan putri yang berjumlah 23 siswa, 14 siswa putra dan 9 siswa putri yang terdiri dari berbagai macam kelas yaitu kelas VII, VIII dan IX. Ekstrakurikuler bolavoli di SMP Negeri 6 Kota Lubuklinggau sudah terlaksana dengan jadwal rutin yang dilakukan dalam seminggu.

Berdasarkan observasi dan wawancara kepada pelatih ektrakurikuler bolavoli Albet Putra, S.Pd yang telah di lakukan pada hari rabu tanggal 22 juli 2020 di SMP Negeri 6 Kota Lubuklinggau, pada saat bermain bolavoli siswa sudah terlihat baik dalam bermain, namun saat melakukan smash masih banyak sekali yang hanya asal-asalan siswa tidak menguasai teknik smash seperti langkah awalan, tolakan untuk melompat dan memukul bola ketika melayang di udara. Setiap siswa melakukan smash bolavoli mempunyai kemampuan yang berbeda-beda terlihat sekali pada saat bermain, itu dikarenakan lemahnya power otot tungkai yang dimiliki setiap siswa tidak sama. Perbedaan terlihat juga pada saat memukul bola sudah ada yang tepat terkena telapak tangan dan ada yang belum, selain itu terdapat siswa yang pada saat melakukan smash bolavoli sering keluar lapangan bahkan menyangkut di net dikarenakan lompatannya kurang tinggi. Teknik yang salah atau tidak tepat juga merupakan salah satu penyebab gagalnya melakukan smash. Prestasi yang pernah diraih tim bola voli ektrakurikular di SMP Negeri 6 Kota Lubuklinggau yaitu menjuarai antar SMP se Kota Lubuklinggau dengan mendapatkan juara harapan dan belum pernah meraih 


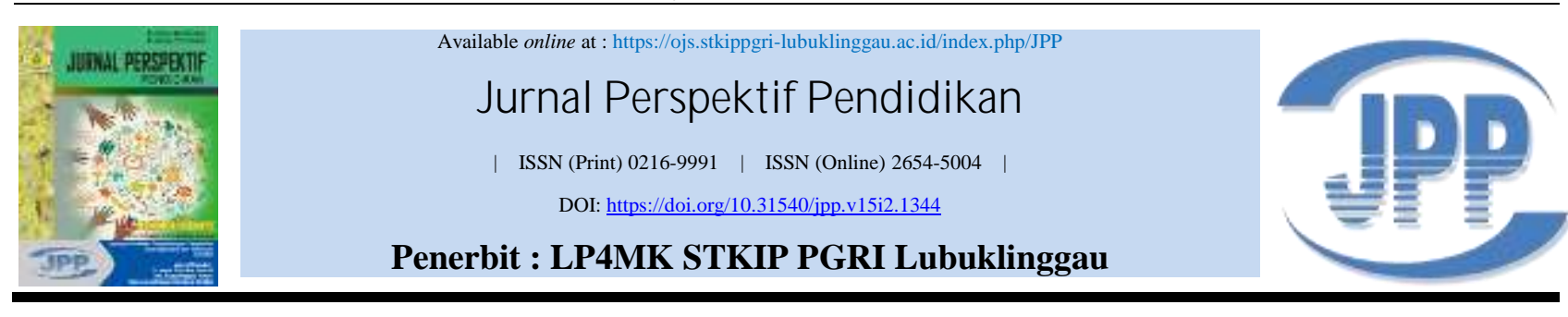

juara satu hal ini dikarenakan tidak ditunjangnya porsi latihan yang baik dan terencana oleh pelatih ektrakurikuler bolavoli yang dilaksanakan dalam seminggu.

Disamping itu unsur dan faktor yang menunjang kemampuan smash tidak diperhatikan. Menurut (Achmad, 2016:80) faktor yang mempengaruhi kemampuan smash bolavoli tersebut antara lain panjang lengan, kekuatan otot lengan, dan daya ledak (power) otot tungkai. Siswa masih menganggap bahwa smash hanyalah sebuah akhir dari suatu permainan, namun untuk sekarang smash sudah merupakan tujuan yang penting untuk mendapatkan angka dalam sebuah pertandingan, karena jika smash dapat dilakukan dengan tepat mengarah pada titik terlemah dari lawan atau ke daerah yang memang susah untuk dijangkau maka keberhasilan dalam memperoleh angka semakin tinggi. Dalam hal ini peneliti bermaksud mengetahui hubungan daya ledak otot tungkai terhadap kemampuan smash dalam permainan bolavoli, yang dilakukan dengan melakukan tes pengukuran terhadap kedua aspek tersebut.

\section{METODE PENELITIAN}

Metode penelitian pada dasarnya merupakan cara ilmiah untuk mendapatkan data dengan tujuan dan kegunaan tertentu. Cara ilmiah berarti kegiatan penelitian itu didasarkan pada ciri-ciri keilmiahan, yaitu: 1) Rasional kegiatan penelitian itu dilakukan dengan cara yang masukakal. 2) Empiris cara-cara yang dilakukan itu dapat diamati oleh inderamanusia. 3) Sistematis, proses yang digunakan dalam penelitian itu menggunakan langkah-langkah tertentu yang bersifat logis (Sugiyono, 2013:3).

Penelitian ini merupakan penelitian korelasional, penelitian korelasional yaitu penelitian yang dilakukan untuk mengetahui ada tidaknya hubungan antara kedua variabel atau beberapa variabel (Arikunto, 2010:313). Variabel pada penelitian ini terdiri pada dua variabel yaitu variabel X dan variabel $\mathrm{Y}$, variabel $\mathrm{X}$ adalah daya ledak otot tungkai dan variabel $\mathrm{Y}$ adalah kemampuan smash. Metode yang digunakan adalah metode korelasi dengan teknik pengumpulan data menggunakan tes dan pengukuran. Penelitian ini bertujuan untuk mengetahui ada tidaknya hubungan antara daya ledak otot tungkai dengan kemampuan smash pada ekstrakurikuler bolavoli di SMP Negeri 6 Kota Lubuklinggau.

\section{HASIL PENELITIAN DAN PEMBAHASAN}

Penelitian dilaksanakan di SMP Negeri 6 Kota Lubuklinggau, SMP Negeri 6 Kota Lubuklinggau merupakan salah satu Kota Lubuklinggau sama dengan SMP pada umumnya di 


\section{Jumal Perspektif Pendidikan}

| ISSN (Print) 0216-9991 | ISSN (Online) 2654-5004 |

DOI: https://doi.org/10.31540/jpp.v15i2.1344

Penerbit : LP4MK STKIP PGRI Lubuklinggau

Indonesia masa pendidikan sekolah di SMP Negeri 6 Kota Lubuklinggau ditempuh dalam waktu tiga tahun pelajaran, mulai dari Kelas VII sampai Kelas IX. Banyak prestasi yang telah ditorehkan oleh sekolah ini baik dari segi akademik maupun non-akademik di tingkat kota, dan yang patut dibanggakan dari sekolah ini adalah metode pembentukan karakter siswa yg diterapkan oleh para guru lewat kegiatan ekstrakurikuler yang dianggap berhasil dan mampu menciptakan generasi siswa yang berkompeten.

Penelitian ini bertujuan untuk mengetahui ada tidaknya hubungan antara varaibel terikat dan variabel bebas dan dalam penelitian ini variabel tersebut yakni daya ledak otot tungkai (x) kemampuan smash bolavoli (y) kedua variable tersebut diteliti dengan memberikan tes berupa tes vertical jump untuk daya ledak otot tungkai dan mengukur kemampuan smash dengan tes smash atau spike, dalam bab ini akan disajikan hasil pengukuran hubungan daya ledak otot tungkai terhadap kemampuan smash pada ekstrakurikuler bolavoli di SMP Negeri 6 Kota Lubuklinggau. Untuk penjelasan selanjutnya masing-masing data akan dideskripsikan sebagai berikut:

\section{a. Deskripsi Data Daya Ledak Otot Tungkai}

Dari hasil tes daya ledak otot tungkai yang dilakukan menggunakan tes vertical jump yang dilakukan sebanyak tiga kali loncatan dimana 3 kali loncatan Hasil dari pengukuran daya ledak otot tungkai (x) dapat dilihat pada tabel dibawah ini:

Tabel 1

Data Daya Ledak Otot Tungkai (x)

\begin{tabular}{|c|c|c|c|}
\hline No. & Nama & Daya Ledak Otot Tungkai & Ket \\
\hline 1 & Siswa 1 & 58 & Cukup \\
\hline 2 & Siswa 2 & 56 & Cukup \\
\hline 3 & Siswa 3 & 58 & Cukup \\
\hline 4 & Siswa 4 & 49 & Sedang \\
\hline 5 & Siswa 5 & 51 & Cukup \\
\hline 6 & Siswa 6 & 45 & Sedang \\
\hline 7 & Siswa 7 & 56 & Cukup \\
\hline 8 & Siswa 8 & 48 & Sedang \\
\hline 9 & Siswa 9 & 55 & Cukup \\
\hline 10 & Siswa 10 & 53 & Cukup \\
\hline 11 & Siswa 11 & 56 & Cukup \\
\hline 12 & Siswa 12 & 47 & Sedang \\
\hline 13 & Siswa 13 & 48 & Sedang \\
\hline 14 & Siswa 14 & 57 & cukup \\
\hline & Total & $\mathbf{7 3 7}$ & \\
\hline
\end{tabular}




\section{Jumal Perspektif Pendidikan}

| ISSN (Print) 0216-9991 | ISSN (Online) 2654-5004 |

DOI: https://doi.org/10.31540/jpp.v15i2.1344

Penerbit : LP4MK STKIP PGRI Lubuklinggau

Pada Tabel di atas dengan nilai tertinggi 58 dan nilai terendah 45. Hasil penyebaran jumlah skor tersebut dapat diketahui dengan nilai rata-rata 52,64.

Selanjutnya nilai daya ledak otot tungkai pada tabel di atas dikelompokan dengan menggunakan tabel norma kreteria vertical jump halaman 31, dapat dilihat sebagai berikut :

Tabel 2

Norma Kreteria Nilai Daya Ledak Otot Tungkai

\begin{tabular}{|c|c|c|}
\hline Hasil loncat tegak & Nilai & Ket \\
\hline $65 \mathrm{~cm}$ keatas & Baik & - \\
\hline $50-65 \mathrm{~cm}$ & Cukup & 9 Siswa \\
\hline $40-49 \mathrm{~cm}$ & Sedang & 5 Siswa \\
\hline $30-39 \mathrm{~cm}$ & Kurang & - \\
\hline Dibawah $30 \mathrm{~cm}$ & Buruk & - \\
\hline \multicolumn{2}{|c|}{ Jumlah } & 14 iswa \\
\hline
\end{tabular}

b. Deskripsi Data Kemampuan Smash

Berdasarkan hasil tes kemampuan smash bolavoli dengan menggunakan tes smash sebanyak 5 kali kesempatan, Hasil nilai distribusi kemampuan smash (y) untuk lebih jelasnya dapat dilihat pada tabel dibawah ini:

Tabel 3

Data Kemampuan Smash (Y)

\begin{tabular}{|c|c|c|c|}
\hline No. & Nama & Smash Bolavoli & Keterangan \\
\hline 1 & Siswa 1 & 18 & Sedang \\
\hline 2 & Siswa 2 & 10 & Kurang \\
\hline 3 & Siswa 3 & 12 & Kurang \\
\hline 4 & Siswa 4 & 15 & Sedang \\
\hline 5 & Siswa 5 & 13 & Kurang \\
\hline 6 & Siswa 6 & 5 & Kurangsekali \\
\hline 7 & Siswa 7 & 16 & Sedang \\
\hline 8 & Siswa 8 & 11 & Kurang \\
\hline 9 & Siswa 9 & 18 & Sedang \\
\hline 10 & Siswa 10 & 19 & Baik \\
\hline 11 & Siswa 11 & 16 & Sedang \\
\hline 12 & Siswa 12 & 9 & Kurang \\
\hline 13 & Siswa 13 & 17 & Sedang \\
\hline 14 & Siswa 14 & 18 & Sedang \\
\hline & & $\mathbf{1 9 7}$ & \\
\hline
\end{tabular}

Pada tabel di atas jumlah skor tertinggi 19 dan skor terendah 5. Hasil penyebaran jumlah skor tersebut dapat diketahui dengan nilai rata-rata 14,07. 


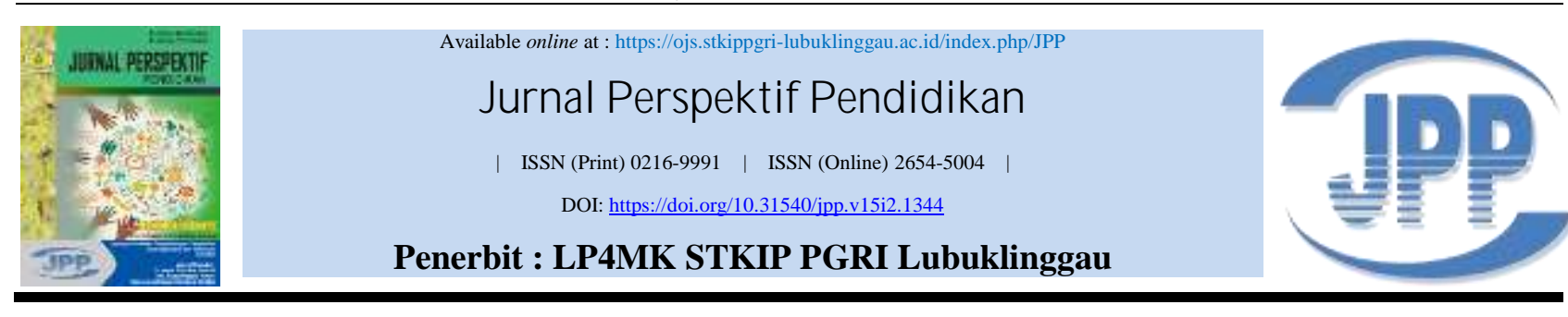

Selanjutnya nilai kemampuan smash pada tabel di atas dikelompokan dengan menggunakan tabel norma kreteria tes smash halaman 33, dapat dilihat sebagai berikut:

Tabel 4

Norma Kreteria Nilai Kemampuan Smash

\begin{tabular}{|c|c|c|c|}
\hline No. & Klasifikasi & Nilai & \multirow{2}{*}{ Ket. } \\
\cline { 3 - 3 } & & Laki-laki & \\
\hline 1. & Baik Sekali & $22-55$ & - \\
\hline 2. & Baik & $19-21$ & 1 \\
\hline 3. & Sedang & $14-18$ & 7 \\
\hline 4. & Kurang & $9-13$ & 5 \\
\hline 5. & Kurang Sekali & $5-8$ & 1 \\
\hline \multicolumn{3}{|c|}{ Jumlah } & 14 \\
\hline
\end{tabular}

1. Pengujian Persyaratan Analisis

Berdasarkan data penelitian yang telah dilakukan sebelum melakukan pengujian hipotesis tentang hubungan kedua variable yaitu variabel bebas dan variabel terikat. Berikut dilakukan uji persyaratan analisis, yaitu uji normalitas daya ledak otot tungkai dengan hasil $\chi_{\text {hitung }}^{2}=$ $2,0119<\chi_{\text {tabel }}^{2}=9,488$ karena $\chi_{\text {hitung }}^{2}<\chi_{\text {tabel }}^{2}$, maka data dapat disimpulkan berdistribusi normal. Sedangkan uji normalitas kemampuan smash dengan hasil $\chi_{\text {hitung }}^{2}=2,6934<\chi_{\text {tabel }}^{2}=$ 9,488 Karena $\chi_{\text {hitung }}^{2}<\chi_{\text {tabel }}^{2}$, maka data dapat disimpulkan berdistribusi normal.

\section{Pengujian Hipotesis}

Uji hipotesis terdapat Hubungan Daya Ledak Otot Tungkai (X) dengan Kemampuan Smash Bolavoli (Y), untuk mengetahui hubungan daya ledak otot tungkai (x) terhadap kemampuan smash bolavoli (y) peneliti menggunakan rumus korelasi product moment dengan hasil perhitungan menunjukan bahwa besar hubungan atau koefisien korelasi antara daya ledak otot tungkai $(\mathrm{X})$ terhadap kemampuan smash bola voli $(\mathrm{Y})$ dengan nilai $\mathrm{r}_{\mathrm{xy}}=0,55$. Dari nilai tersebut dapat didefinisikan hubungan antara kedua variabel dimana nilainya adalah 0,55 dalam interval 0,40-0,599 yang menyatakan hubungan antara kedua variabel tersebut dinyatakan sedang.

Untuk mengetahui ada dan tidak adanya hubungan yang signifikan antara daya ledak (power) otot tungkai dengan kemampuan smash siswa ekstrakurikuler bolavoli di SMP Negeri 6 Kota Lubuklinggau. Maka dilakukan dengan peghitungan $t_{\text {hitung }}$ dan $t_{\text {tabel, }}$ jika $t_{\text {hitung }}>t_{\text {table }}$ maka 


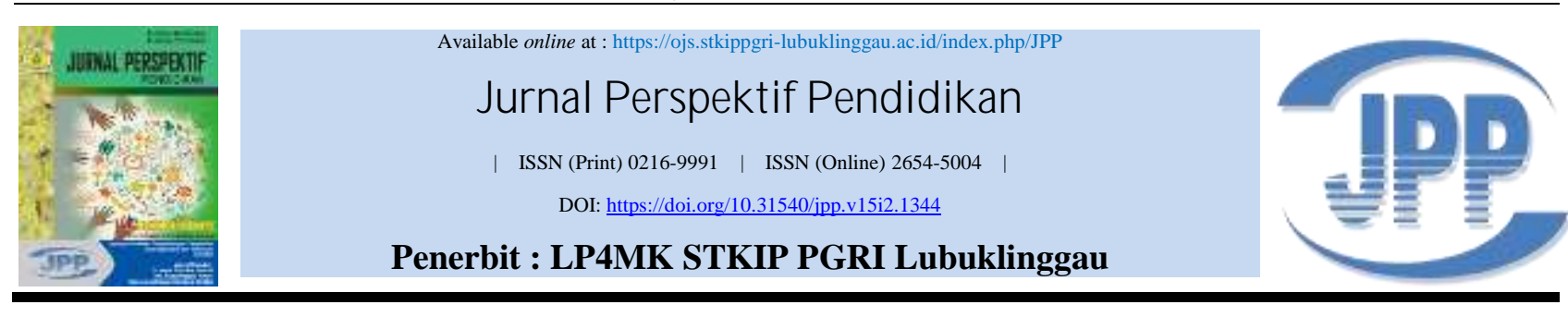

Ha diterima atau sebaliknya jika $t_{\text {hitung }}<t_{\text {table }}$ maka Ho diterima, dalam penelitian diperoleh nilai $t_{\text {hitung }}=2,280>t_{\text {tabel }}=2,178$ maka Ha dapat diterimah dan Ho ditolak maka dapat disimpulkan ada hubungan yang signifikan antara daya ledak otot tungkai dengan kemampuan smash pada siswa ekstrakurikuler bolavoli di SMP Negeri 6 Kota Lubuklinggau atau hipotesis alternatif diterima.

Berdasarkan hasil analisis data yang telah dilakukan peneliti, didapatkan hasil yang menunjukan bahwa ada hubungan antara daya ledak otot tungkai dengan kemampuan smash. Hasil analisis tersebut didapatkan dari perhitungan dengan menggunakan rumus product moment yang diketahui besarnya hubungan antara kedua variabel adalah 0,55 . Nilai tersebut menyatakan bahwa tingkat hubungan antara kedua variabel dalam kategori sedang, pernyataan ini diambil dari tabel interpretasi koefisien korelasi oleh Sugiyono (2013:257). Dari hasil analisis data juga meyatakan bahwa ada hubungan yang signifikan antara daya ledak otot tungkai dengan kemampuan smash bolavoli dalam penelitian ini dengan nilai $t_{\text {hitung }}=2,280>t_{\text {tabel }}=2,178$.

Besarnya sumbangan daya ledak otot tungkai terhadap kemampuan smash bolavoli memberikan kontribusi yang positif yang artinya semakin tinggi daya ledak otot tungkai seorang pemain bolavoli maka hasil smash yang diperoleh akan semakin baik dan sebaliknya semakin rendah daya ledak otot tungkai seorang pemain bolavoli maka smash yang diperoleh akan semakin buruk, menurut (Sajoto, 2015:18).

Daya ledak adalah kemampuan seseorang untuk mempergunakan kekuatan maksimum yang dikerahkan dalam waktu yang sependek-pendeknya. Kemampuan smash pada ketinggian maksimal dapat diperoleh dari tingginya daya ledak otot tungkai pemain atau lompatan yang tinggi melebihi net dengan demikian sangat beralasan apabila dalam penelitian ini diperoleh temuan bahwa daya ledak otot tungkai berhubungan dengan kemampuan smash bolavoli.

Daya ledak otot tungkai yang dimiliki pemain bolavoli di SMP Negeri 6 Kota Lubuklinggau sudah cukup baik dapat dilihat pada tabel lampiran tes vertical jump, hanya saja perlu latihan dan pengembangan lagi guna mencapai hasil yang baik. Hal ini dilihat dari skor daya ledak otot tungkai yang sudah dilakukan para pemain dimana saat dilakukan test vertical jump hasilnya masih ada beberapa siswa dari sampel yang dilakukan, loncatan yang dihasilkan masih kurang maksimal, hal ini dapat berpengaruh pada kemampuan smash pada pemain menjangkau bola pada saat melayang 


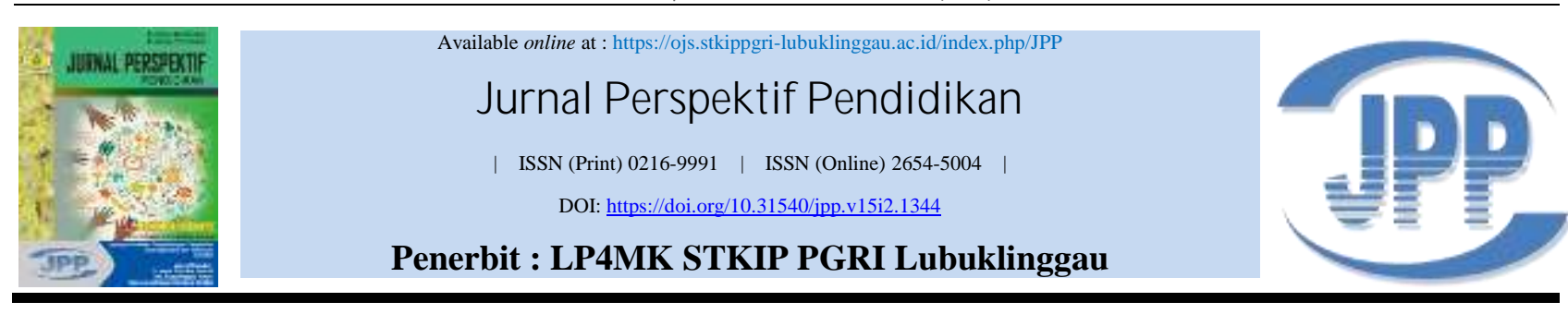

di udara dalam permainan bolavoli, lemahnya daya ledak otot tungkai akan menghasilkan loncatan yang rendah.

\section{KESIMPULAN}

Berdasarkan penelitian yang dilakukan di SMP Negeri 6 Kota Lubuklinggau pada siswa ekstrakurikuler bolavoli dan analisis data yang didapat, maka penulis menarik kesimpulan terhadap permasalahan-permasalahan dalam penelitian, sebagai berikut: Hasil perhitungan menunjukan bahwa terdapat hubungan antara daya ledak otot tungkai (X) dengan kemampuan smash bolavoli (Y) adalah $r_{x y}=0,55$ dari nilai tersebut dapat dikategorikan sedang, dimana nilai 0,55 dalam interval di posisi 0,40 - 0,599. Hubungan antara daya ledak otot tungkai dengan kemampuan smash pada siswa ekstrakurikuler bolavoli di SMP Negeri 6 Kota Lubuklinggau, kedua variabel ada hubungan yang signifikan dinyatakan berdasarkan pada taraf signifikan $\alpha=0,05$ yang dimana $t_{\text {hitung }}$ $=2,280>$ dari $t_{\text {tabel }}=2,178$.

\section{DAFTAR PUSTAKA}

Arikunto, Suharsimi. 2010. Prosedur Penelitian Suatu Pendekatan Praktik. Jakarta: PT. Rineka Cipta.

Afridawati, 2013. Evaluasi, Tes dan Pengukuran Olahraga. Palembang: RD Multicipta

Anam Khoerul, dkk. 2015. Klub Bolavoli Putra Ivokas Kabupaten Semarang. Journal Of Sport Sciences, 4 (1) : 40-49.

Achmad, Z.I. 2016. Hubungan Antara Power Tungkai, Koordinasi Mata-Tangan dan Rasa Percaya Diri Dengan Hasil Keterampilan Open Spike Bolavoli. Jurnal Pendidikan Unsika, Vol 4. No $1: 78-90$.

Hidayat Witono. 2017. Buku Pintar Bolavoli, Jakarta: Anugrah.

Kedeo, F.E. 2013. Komtribusi Kelentukan Togok, Daya Ledak Otot Tungkai dan Kekuatan Otot Lengan Terhadap Kemampuan Smash Dalam Permainan Bolavoli Pada Club Voli Kecamatan Lore Tengah Desa Lempe. Program sarjana. Universitas Tadulako. Journal Tadulako Physical Education, Health And Recreation, Vol 1. No 5 : 1-12.

Kurniawan, Feri. 2011. Buku Pintar Olahraga. Jakarta: Laskar Aksara

Kemendiknas. 2014. Mengukur Kemampuan Kebugaran Jasmani. Jakarta: Balai Bahasa.

La Anse. 2017. Hubungan Power Otot Tungkai Dengan Kemampuan Tendangan Lurus Pencak Silat Pada Club Perisai Putih Kabupaten Lolaka Timur. Jurnal Ilmu Keolahrgaan, Vol. 16 (1) : 47-56. 


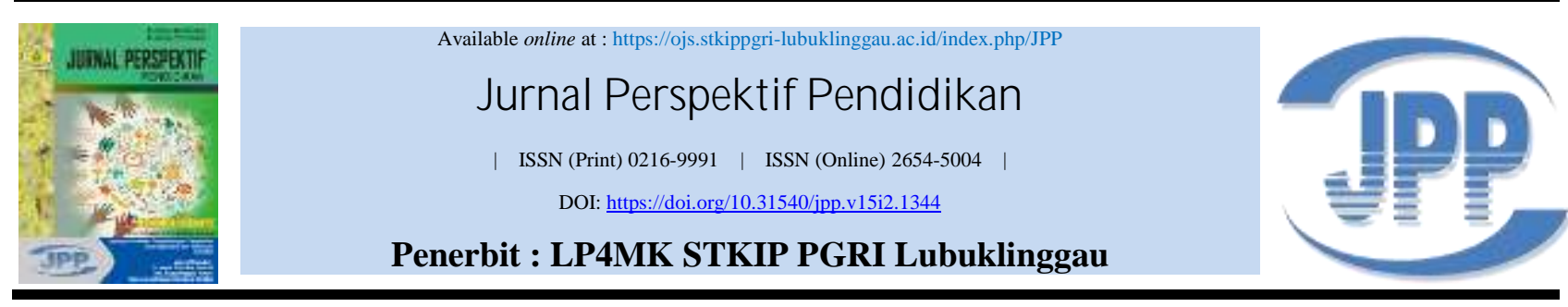

Mardiana. 2017. Analisis Daya Ledak Tungkai, Kecepatan Lari Dan Panjang Tungkai Terhadap Kemampuan Lompat Jauh Siswa SMA Negeri 2 Watampone Kabupaten Bone. Jurnal Ilmiah Ilmu Pendidikan, Vol. 1. No. 2.

Sajoto, M. 2015. Peningkatan Dan Pembinaan Kondisi Fisik Dalam OLahraga. Semarang: Dahar Prize.

Setiono, A.H, dkk. 2013. Sumbangan Kekuatan Otot Tungkai Dan Kelentukan Pergelangan Kaki Terhadap Keterampilan Menggiring Bola Pada Pemain Ssb Ika Undip Tahun 2012. Program Sarjana: Universitas Negeri Semarang. Journal off Sport Sciences and Fitnes, 2 (2) : 39-43.

Sugiyono. 2013. Metode Penelitian Pendidikan Pendektan Kuantitatif, Kualitatif, dan R\&D. Bandung: Alpabeta.

Sunardi dan Deddy Whinata Kardiyanto, 2013. Bolavoli. UNS Press

Sukirno dan Waluyo. 2012. Cabang Olahraga Bolavoli. Palembang: Unsri Press.

Widiastuti, 2011. Tes dan Pengukuran Olahraga. Jakarta: PT Bumi Timur Jaya.

Yulifri, dkk. 2018. Hubungan Daya Ledak Otot Tungkai Dan Otot Lengan Dengan Ketepatan Smash Atlet Bolavoli Gempar Kabupaten Pasaman Barat. Jurnal Menssana, Vol. 3 No. 1 : 19-32. 